Joana S. Amaral · Susana Casal • Ivana Citová •

Alberto Santos • Rosa M. Seabra •

Beatriz P. P. Oliveira

\title{
Characterization of several hazelnut (Corylus avellana L.) cultivars based in chemical, fatty acid and sterol composition
}

Received: 25 February 2005 / Published online: 21 September 2005 (C) Springer-Verlag 2005

\begin{abstract}
Nineteen cultivars of hazelnuts (Corylus avellana L.) collected during the 2001 crop, from Vila Real, Portugal, were analysed for chemical composition, including moisture, total oil content, crude protein, ash, carbohydrates and nutritional value. Fat was the predominant component, ranging from 59.3 to $69.0 \%$. Total oil was extracted and analysed for fatty acid and sterol compositions and oxidative stability. Fatty acid and sterol compositions were determined by Gas-Liquid Chromatography coupled to a Flame Ionisation Detector (GLC/FID). Monounsaturated fatty acids, particularly oleic acid, were predominant (78.7-84.6\%). Total phytosterol content ranged from 133.8 to $263.0 \mathrm{mg} / 100 \mathrm{~g}$ of oil. Among the nine sterols identified and quantified, $\beta$-sitosterol was the major one with a mean percentage of $83.6 \%$, while $\Delta^{5}$-avenasterol and campesterol were the second and the third components of the group with mean values of 6.1 and $5.8 \%$, respectively. Since hazelnut oil can be used in olive oil adulteration, the values obtained were compared with published mean values of olive oils from different geographical origins.
\end{abstract}

J. S. Amaral · R. M. Seabra ( $₫)$

REQUIMTE, Serviços de Farmacognosia, Universidade do Porto,

R. Aníbal Cunha, 164,

4099-030 Porto, Portugal

e-mail: rseabra@ff.up.pt

Tel.: +351-222078934

Fax: +351-222003977

\section{J. S. Amaral}

Escola Superior de Tecnologia e de Gestão, Instituto Politécnico de Bragança, Quinta de Sta. Apolónia,

Apartado 134,

5301-857 Bragança, Portugal

S. Casal · I. Citová · B. P. P. Oliveira

REQUIMTE, Bromatologia, Faculdade de Farmácia,

Universidade do Porto,

R. Aníbal Cunha, 164,

4099-030 Porto, Portugal

A. Santos

Universidade de Trás-os-Montes e Alto Douro, 5001-911 Vila Real, Portugal
Keywords Corylus avellana L. · Hazelnut oil · Nutritional value $\cdot$ Chemical composition $\cdot$ Fatty acid composition . Sterol composition $\cdot$ Olive oil

\section{Introduction}

Populations from Mediterranean countries, when compared with those from US and northern Europe, present lower mortality rates from coronary heart disease (CHD) and cancer, which could be related to the consumption of the typical Mediterranean diet [1,2]. This diet is low in meat and higher in fish, fruits and vegetables, also having nuts as valuable components. Although nuts are rich in fat, they are generally low in saturated fatty acids (SFA) and high in monounsaturated (MUFA) and polyunsaturated (PUFA) fatty acids. There is evidence that a MUFA rich diet can lower the risk on CHD and also has preventive effects on atherosclerosis [3-5]. There is also a growing interest in evaluating nut's role in a heart-healthy diet and several studies have been made supporting a role for nuts in reducing CHD risk $[2,6-8]$.

Among nut species, hazelnuts are widely appreciated. Besides being consumed as a fruit they are mainly used as an ingredient in confectionary products, as raw materials for pastry and chocolate industry, and also add flavour and texture to an increasing variety of sweet and savoury food products such as bakery, cereal and dessert formulations [9]. Hazelnuts are about $60 \%$ fat (fresh weight) with oleic acid being the major fatty acid. Besides a favourable fatty acid profile, hazelnuts are rich in phytosterols, which are known for their ability in reducing blood cholesterol, but have also been reported to have anticancer and immune system modulating properties [10-13].

The possibility of using hazelnut oil in adulteration of olive oil is another issue of current interest [14-22]. In fact, adulteration of virgin olive oil with other cheap vegetable oils has frequently represented a problem for regulatory agencies, oil suppliers and consumers. Assessment of authenticity of vegetable oils in the food industry involves many tests, being the analysis of fatty 
acids and sterol compositions currently used [23-26]. Since hazelnut and olive oils have similar lipidic compositions, adulterations are difficult to detect. Fatty acids [20], triacylglycerols [15, 20], sterols [15, 18], tocopherols [15] and polar components [21] have already been used with this purpose.

As the cultivar and geographical origin are important factors that can influence compositional values [27-30] it is important to characterize (qualitatively and quantitatively) hazelnut oil composition in order to draw up profiles that will not only bring more information in what hazelnut oil composition is concerned, but can also be used in future works concerning virgin olive oil adulterations. As possible, comparisons of hazelnut and olive oils are discussed.

In this study, 19 cultivars of hazelnuts growing in the same experimental orchard and subjected to the same agricultural practices were analysed. In this way, any variability found among the samples can be attributed to the influence of the cultivar. Samples were analysed for total fat, moisture, crude protein, ash, carbohydrates and oxidative stability. The chemical study was extended to 15 fatty acids and 9 phytosterols. Some works have already been published concerning some of the parameters studied in the work herein, but some reported only mean values without referring the cultivars under study [23, 26, 31, 32], other works studied different cultivars [27, 28, 30,33] and other studied a reduced number of cultivars [34-38]. As far as we know, this is the first report on hazelnut cultivars grown in Portugal and nine of the cultivars were now studied for the first time.

\section{Materials and methods}

\section{Chemicals}

The standard mixture of 37 FAMEs and the fatty acid isom-

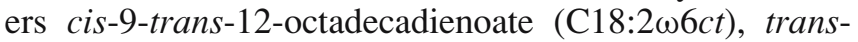

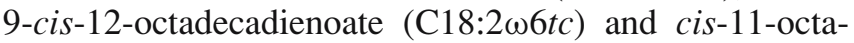
decenoate $(\mathrm{C} 18: 1 \omega 7)$ were all purchased from Supelco (Bellefont, PA, USA). Betulin, cholestanol, cholesterol, campesterol, stigmasterol, $\beta$-sitosterol, $\beta$-sitostanol, 1 methylimidazole and boron trifuoride methanol solution, $14 \%\left(\mathrm{BF}_{3}\right)$ were all from Sigma (St. Louis, MO, USA). $N$-methyl- $N$-(trimethylsilyl)-hepta-fluorobutyramide (MSHFBA) was obtained from MachereyNagel (Düren, Germany).

\section{Samples}

Nineteen hazelnut (Corylus avellana L.) cultivars (Butler, Campanica, Cosford, Couplat, Daviana, Ennis, Fertille de Coutard, Grossal, Gunslbert, Lansing, Longa d'Espanha, Merveille de Bolwiller, Morell, Negreta, Pauetet, Round du Piemont, Santa Maria de Jesus, Segorbe and Tonda de Giffoni) were studied. An experimental plantation was established in March 1984, in Vila Real, in the northeastern region of Portugal $\left(41^{\circ} 19^{\prime} \mathrm{N}, 7^{\circ} 44^{\prime} \mathrm{W}, 470 \mathrm{~m}\right.$ elevation). The trees were planted at a $5 \times 3 \mathrm{~m}$ spacing with no pruning, in a completely randomised design for fruit sampling. The hazelnuts were harvested in the crop year 2001 (September) and a final sample of about $2 \mathrm{~kg}$ was randomly taken. After harvest, hazelnut fruits were dried at ambient temperature in the dark. The fruits were stored in shell, closed in plastic bags, flushed with nitrogen, and frozen to $-20{ }^{\circ} \mathrm{C}$, until the analyses.

\section{Sample preparation}

Before chemical analysis the hazelnuts were manually cracked and shelled, and then chopped in a $643 \mathrm{MX}$ coffee mill (Moulinex, Spain). Crude oil was obtained from finely chopped nuts (ca. $15 \mathrm{~g}$ ) extracted with light petroleum ether (b.p. $40-60^{\circ} \mathrm{C}$ ) in a Soxhlet apparatus; the remaining solvent was removed by vacuum distillation. The extracted oil was stored at $4{ }^{\circ} \mathrm{C}$ in tubes with anhydrous sodium sulphate, protected from light with aluminium foil and flushed with nitrogen.

\section{Chemical analysis}

Moisture, total fat, ash and protein contents analysis were carried out in duplicate. Moisture was determined at $100 \pm 2{ }^{\circ} \mathrm{C}$ (ca. $5 \mathrm{~g}$ test sample) using an SMO 01 infrared moisture balance (Scaltec, Goettingen, Germany). Ash, crude protein $(N \times 5.3)$ and total fat contents were determined according to AOAC Official Methods [39]. The percentage of total carbohydrates was calculated subtracting the total percentage of the other components from 100. Energy was expressed as kcal, using the factors proposed by Greenfield and Southgate [40].

\section{Oxidative stability (OS)}

The oxidation induction time was measured on a Rancimat apparatus (Metrohm CH series 679, Herisau, Switzerland). A flow of air $(20 \mathrm{l} / \mathrm{h})$ was bubbled through the oil (ca. $3.0 \mathrm{ml}$ ) heated at $110 \pm 0.2{ }^{\circ} \mathrm{C}$. The volatile oxidation products released were led into a conductivimetric cell containing water, while the change of conductivity of the solution was plotted on a graph. OS was determined as the time taken to reach the conductivity inflection point, and recorded as the induction time (IT).

\section{Fatty acid composition}

Fatty acids were determined by GLC/FID/capillary column using the same methodology as Amaral et al. [41]. Fatty acids were measured as their methyl esters after hydrolysis with a $11 \mathrm{~g} / \mathrm{l}$ methanolic potassium hydroxide solution, methyl esterification with $\mathrm{BF}_{3} / \mathrm{MeOH}$ and extraction with $n$-heptane. The analysis was carried out on a Chrompack CP 9001 chromatograph (Chrompack, Middelburg, The 
Netherlands) equipped with a split-splitless injector, a FID and a Chrompack CP-9050 autosampler. The temperatures of the injector and detector were $230^{\circ} \mathrm{C}$ and $270{ }^{\circ} \mathrm{C}$, respectively. Separation was achieved on a $50 \mathrm{~m} \times 0.25 \mathrm{~mm}$ i.d. fused silica capillary column coated with a $0.19 \mu \mathrm{m}$ film of CP-Sil 88 (Chrompack, Middelburg, The Netherlands). The column temperature was $160{ }^{\circ} \mathrm{C}$ held for $1 \mathrm{~min}$, and then programmed to increase to $239^{\circ} \mathrm{C}$ at a rate of $4{ }^{\circ} \mathrm{C} / \mathrm{min}$ and then held for $10 \mathrm{~min}$. Helium was used as carrier gas at an internal pressure of $120 \mathrm{kPa}$. The split ratio was 1:50 and the injected volume was $1.2 \mu$ l. The results are expressed in relative percentage of each fatty acid, calculated by internal normalization of the chromatographic peak area. Fatty acids were identified by comparing the relative retention times of FAMEs peaks from samples with standards.

\section{Sterol composition}

Sterol composition was evaluated by GLC/FID/capillary column following the NP EN ISO 12228 method [42]. Briefly, after addition of $1.0 \mathrm{ml}$ of internal standard solution (betulin $1.0 \mathrm{mg} / \mathrm{ml}$ ) ca. $250 \mathrm{mg}$ of oil was saponified with an ethanolic potassium hydroxide solution; the unsaponifiable fraction was isolated by solid phase extraction on an aluminium oxide column and the steroid fraction was obtained after TLC with $n$-hexane/diethyl ether 1:1 (v/v) as developing solvent and a methanol spray to visualize the band. The trimethylsilyl ethers were obtained by the addition of 1-methylimidazole and MSHFBA. The sterol profile was analysed on the same equipment used for fatty acid analysis, with a $30 \mathrm{~m} \times 0.25 \mathrm{~mm}$ i.d., $0.25 \mu \mathrm{m}$ DB5MS column (J \& W Scientific, Folsom, CA, USA) with a maximum operating temperature of $325^{\circ} \mathrm{C}$. The temperature of the injector and the detector were both $320^{\circ} \mathrm{C}$. The column temperature was $250{ }^{\circ} \mathrm{C}$ and programmed to increase at a rate of $2{ }^{\circ} \mathrm{C} / \mathrm{min}$ to $300{ }^{\circ} \mathrm{C}$ and then held for $12 \mathrm{~min}$. The carrier gas used was helium at an internal pressure of $100 \mathrm{kPa}$. The split ratio was 1:50 and the injected volume was $1.5 \mu \mathrm{l}$. Total sterol content was determined considering all peaks of sterols eluted between cholesterol and $\Delta^{7}$-avenasterol. Identification was achieved by comparing the relative retention times from samples with those obtained with standards. Clerosterol, $\Delta^{5}$-avenasterol, $\Delta^{7}$ stigmastenol and $\Delta^{7}$-avenasterol were tentatively identified by comparison with references [23, 26, 41] and with samples of olive and sunflower oils. $\beta$-Sitostanol and $\Delta^{5}$ avenasterol eluted very close and therefore were quantified as $\Delta^{5}$-avenasterol.

\section{Results and discussion}

The proximate composition results and caloric value of the studied samples are showed in Table 1. Fat was the predominant component with a mean value of $(64.0 \%)$ and ranging from $59.3 \%$ in $c v$. Merveille de Bollwiller to $69.0 \%$ in $c v$. Negreta. The cultivars grown in Portugal, generally presented higher values for fat content when compared to the average values of hazelnuts grown in Spain (56.1\%) [32], in New Zealand (58.4\%) [33] and in Turkey (59.8\%) [9], but identical values to hazelnuts grown in Italy $(64.1 \%)$ [36]. As already pointed out, several factors can be responsible for these variations, besides the nature of the cultivar. To illustrate this, we can point the differences registered between the oil contents of cvs. Butler, Campanica, Ennis and

Table 1 Proximate chemical composition (g/100 g fresh weight) of 19 hazelnut cultivars grown in Portugal (mean \pm SD)

\begin{tabular}{lllllll}
\hline Cultivar & Moisture & Crude protein & Lipid & Ash & Carbohidrates & Energy (kcal) \\
\hline Butler & $4.36 \pm 0.04$ & $11.27 \pm 0.08$ & $61.79 \pm 1.90$ & $2.72 \pm 0.02$ & $19.86 \pm 1.54$ & 681 \\
Campanica & $4.68 \pm 0.09$ & $10.80 \pm 0.20$ & $64.95 \pm 0.25$ & $2.74 \pm 0.02$ & $16.83 \pm 0.37$ & 695 \\
Cosford & $4.52 \pm 0.23$ & $10.20 \pm 0.01$ & $61.96 \pm 0.07$ & $2.59 \pm 0.02$ & $20.73 \pm 0.22$ & 681 \\
Couplat & $3.75 \pm 0.09$ & $9.90 \pm 0.07$ & $67.00 \pm 0.22$ & $2.44 \pm 0.03$ & $16.91 \pm 0.38$ & 710 \\
Daviana & $5.35 \pm 0.06$ & $11.37 \pm 0.06$ & $60.92 \pm 0.07$ & $2.90 \pm 0.00$ & $19.47 \pm 0.07$ & 672 \\
Ennis & $6.43 \pm 0.04$ & $9.48 \pm 0.07$ & $60.19 \pm 0.08$ & $2.80 \pm 0.09$ & $21.11 \pm 0.07$ & 664 \\
F. Coutard & $6.29 \pm 0.16$ & $10.89 \pm 0.09$ & $62.67 \pm 0.23$ & $2.69 \pm 0.08$ & $17.46 \pm 0.37$ & 677 \\
Grossal & $5.20 \pm 0.17$ & $9.57 \pm 0.03$ & $65.29 \pm 0.17$ & $2.53 \pm 0.08$ & $17.41 \pm 0.39$ & 696 \\
Gunslbert & $5.85 \pm 0.19$ & $12.62 \pm 0.16$ & $60.16 \pm 0.51$ & $3.39 \pm 0.06$ & $17.99 \pm 0.82$ & 664 \\
Lansing & $4.89 \pm 0.05$ & $10.09 \pm 0.10$ & $63.05 \pm 0.02$ & $2.82 \pm 0.01$ & $19.15 \pm 0.10$ & 684 \\
L. Espanha & $3.79 \pm 0.08$ & $10.27 \pm 0.00$ & $65.39 \pm 0.14$ & $2.62 \pm 0.01$ & $17.93 \pm 0.06$ & 701 \\
M. Bollwiller & $4.61 \pm 0.10$ & $12.69 \pm 0.06$ & $59.25 \pm 0.16$ & $3.06 \pm 0.05$ & $20.39 \pm 0.02$ & 666 \\
Morell & $4.12 \pm 0.21$ & $10.83 \pm 0.01$ & $64.77 \pm 0.09$ & $2.42 \pm 0.06$ & $17.87 \pm 0.23$ & 698 \\
Negreta & $3.46 \pm 0.20$ & $10.58 \pm 0.03$ & $69.03 \pm 0.19$ & $2.43 \pm 0.01$ & $14.50 \pm 0.28$ & 722 \\
Pauetet & $5.62 \pm 0.27$ & $10.72 \pm 0.08$ & $65.65 \pm 0.13$ & $2.57 \pm 0.00$ & $15.45 \pm 0.09$ & 695 \\
R. Piemont & $4.19 \pm 0.04$ & $10.93 \pm 0.06$ & $66.69 \pm 0.01$ & $2.40 \pm 0.02$ & $15.79 \pm 0.01$ & 707 \\
Segorbe & $4.85 \pm 0.19$ & $12.38 \pm 0.05$ & $63.02 \pm 0.32$ & $2.57 \pm 0.01$ & $17.19 \pm 0.31$ & 685 \\
St. M. Jesus & $4.39 \pm 0.09$ & $12.40 \pm 0.04$ & $68.30 \pm 1.48$ & $2.81 \pm 0.01$ & $12.09 \pm 1.41$ & 713 \\
T. Giffoni & $6.30 \pm 0.04$ & $9.34 \pm 0.17$ & $65.30 \pm 0.05$ & $2.63 \pm 0.05$ & $16.44 \pm 0.18$ & 691 \\
Mean & 4.87 & 10.86 & 63.97 & 2.69 & 17.61 & 689.57 \\
Range & $3.5-6.4$ & $9.3-12.7$ & $59.2-69.0$ & $2.4-3.4$ & $12.1-21.1$ & $664-722$ \\
\hline
\end{tabular}




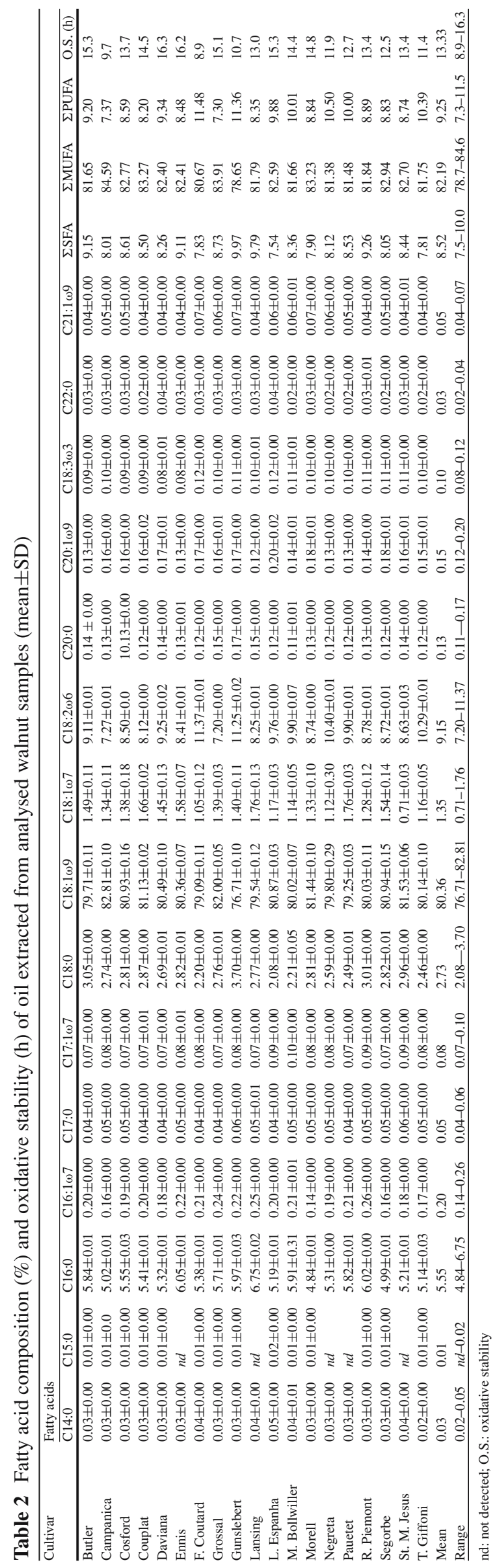

Tonda de Giffoni, that in this study showed values of 61.8 , $64.9,60.2$ and $65.3 \%$, respectively, while the same cultivars collected during 1995 in New Zealand presented values of $57.1,56.1,54.6$ and $63.2 \%$, respectively [33]. The caloric value of the studied cultivars was in average $690 \mathrm{kcal} / 100 \mathrm{~g}$ of hazelnuts, confirming that these fruits are a good source of energy.

Table 2 reports the results obtained for fatty acid composition, total saturated fatty acids (SFA), monounsaturated fatty acids (MUFA), polyunsaturated fatty acids (PUFA) and the oxidative stability of the studied cultivars. Fifteen fatty acids were identified in Portuguese samples, among which oleic acid $(\mathrm{C} 18: 1 \omega 9)$ was by far the predominant one ranging from $76.7 \%$ in $c v$. Gunslbert to $82.8 \%$ in $c v$. Campanica. The second, third, fourth and fifth acids were always linoleic $(\mathrm{C} 18: 2 \omega 6)$, palmitic $(\mathrm{C} 16: 0)$, stearic $(\mathrm{C} 18: 0)$ and vaccenic $(\mathrm{C} 18: 1 \omega 7)$ acids with mean values of 9.2, 5.6, 2.7 and $1.4 \%$, respectively. All other acids were present in amounts lower than $1 \%$. The individual fatty acid content was, in general terms, in agreement with those already reported to occur in other hazelnuts cultivars [27-29, 31, 33-36]. As expected, MUFA was the main group of fatty acids. PUFA and SFA contents were in the same order of magnitude, although the percentages of PUFA were slightly higher in almost all the studied cultivars. It has been reported that the ratio of oleic to linoleic acid varies among hazelnut cultivars and that their contents were inversely related $[28,34]$. This is reasonably consistent with the results herein reported, since the cvs. Campanica and Grossal were the ones with higher oleic acid and lower linoleic acid contents while cvs. Gunslbert and Fertille de Coutard were the ones with lower oleic and higher linoleic acid contents. However, this relation was not observed for all the cultivars. The ratio oleic to linoleic acid varied from 6.8 to 11.4 and this can really point to different behaviours for the several cultivars studied.

When comparing the fatty acid profile of olive oils from different countries [43-45] with the one herein reported for hazelnuts, they seem to be slightly different since in olive oil the second and third major fatty acids are always palmitic and linoleic acids, while in hazelnut oils this order is the inverted one. Consequently, total SFA content in hazelnuts is lower than in olive oils.

The values obtained for oxidative stability are listed in Table 2 and ranged from 8.9 to $16.3 \mathrm{~h}$. The induction times (IT) obtained with the cultivars grown in Portugal, were higher than those reported for cultivars grown in Spain by Parcerisa et al. (2.8-10.0 h) [37] and by Bonvehí and Coll (4.4-9.6 h) [38], what can be explained by the different temperatures used on the apparatus. No matter what, on comparing the values obtained with the now studied cultivars Couplat (14.5 h), Morell (14.8 h), Negreta (11.9 h) and Pauetet $(12.7 \mathrm{~h})$ with the values obtained by Bonheví and Coll [38] for the same cultivars $(9.0,8.8,5.7$ and $6.9 \mathrm{~h}$, respectively) in both studies cvs. Negreta and Pauetet were the ones with lower stability, and this points to differences in resistance to oxidation among cultivars. Research has shown that IT is related mainly with two parameters: the degree of saturation of the fatty acids present in the oil 
(the higher the degree of unsaturation the lower the IT and, consequently, the shelf life), and the presence of natural antioxidants and prooxidants in the oil. On analysing the IT of the samples now studied it can be observed that the obtained values are not strictly related with the PUFA amounts. This may therefore be attributed to variations in the nature and amounts of tocopherols or phytosterols which are known to have some antioxidants properties. For instance, the high IT obtained for $c v$. Daviana may probably be due, at least in part, to an abnormally high amount of phytosterols.

The obtained values for total phytosterol contents in the studied samples were in good agreement with the mean values described for hazelnuts [23, 27]. There were, however, important differences among the studied cultivars, from the lowest content in $c v$. Grossal $(133.8 \mathrm{mg} / 100 \mathrm{~g}$ oil $)$ to the highest in $c v$. Daviana $(263.0 \mathrm{mg} / 100 \mathrm{~g}$ oil). The identified compounds are listed in Table 3. $\beta$-sitosterol was the major sterol found in all cultivars, followed by $\Delta^{5}$-avenasterol and campesterol, approximately in the same order of magnitude. Besides these compounds, cholesterol, stigmasterol, clerosterol and $\Delta^{7}$-avenasterol were also found in all samples. The presence of cholestanol was also checked but it was not detected. Qualitative differences among the studied cultivars were only found for $\Delta^{7}$-stigmastenol that was not detected in four of the cultivars.

Parcerisa et al. [32] studied 17 cultivars grown in USA, and 7 of them (cvs. T. Giffoni, Segorbe, Negreta, F. Coutard, Daviana, Butler and Ennis) were common with the ones herein studied. In general, the individual and consequently the total phytosterol content were lower (93.9$153.9 \mathrm{mg} / 100 \mathrm{~g}$ of oil) in the cultivars grown in USA than in the same 7 cultivars grown in Portugal and herein studied (163.0-263.0 mg/100 $\mathrm{g}$ of oil). When comparing relative percentages, the cultivars studied by Parcerisa et al. [29] presented higher values for $\beta$-sitosterol (85.3-90.8\%) than those grown in Portugal (82.1-85.6\%). This may be due to the fact that only four sterols were detected and quantified in that work (campesterol, stigmasterol, $\beta$-sitosterol and $\Delta^{5}$-avenasterol).

The evaluation of the total sterol content and the sterol profile have already been used as a tool to assess vegetable oils authenticity [15, 16, 23-26, 31, 47, 49], and according to some authors can be a useful tool methods for the control of adulterations of olive oil with hazelnut oil $[15,16]$. The adulteration of olive oil with high amounts of hazelnut oil can be checked by the study of the sterol profile. In fact, when comparing hazelnut and olive oils sterol profiles (Tables 3 and 4) important qualitative and quantitative differences can be observed. When taking into account the regulations established by the European Union, the Codex Alimentarius of the FAO/WHO and by the International Olive Oil Council, all of the hazelnut studied samples exceeded the upper limit of $4 \%$ established by the EU (Regulation 2568/91/EEC and later amendments) for olive oil campesterol content; besides, hazelnut samples exceeded the established upper limits of cholesterol $(0.5 \%)$ (except $c v s$. Daviana and Grossal) and of $\Delta^{7}$-stigmastenol $(\leq 0.5 \%)$ (except cvs. Cosford, Daviana, Ennis, Lansing, L. Espanha, M. Bollwiller and Segorbe). The European Union also establishes that the apparent $\beta$-sitosterol content (sum of clerosterol, $\beta$-sitosterol, $\Delta^{5}$-avenasterol, $\beta$-sitosterol and $\Delta^{5,24}$-stigmastenol) in olive oils should be $\geq 93 \%$, but in the studied hazelnut cultivars those values ranged from 90.0 to $93.5 \%$ and only four cultivars were within the limits imposed for olive oils. From the results here reported it seems that the sterol profile allows differentiating between

Table 3 Sterol content $(\mathrm{mg} / 100 \mathrm{~g}$ of oil) of oil extracted from hazelnut samples (mean \pm SD)

\begin{tabular}{|c|c|c|c|c|c|c|c|c|c|}
\hline Cultivar & Cholesterol & Campesterol & Stigmasterol & Clerosterol & $\beta$-Sitosterol & $\begin{array}{l}\beta \text {-Sitostanol } \\
+\Delta^{5} \text {-Avenasterol }\end{array}$ & $\Delta^{7}$-Stigmastenol & $\Delta^{7}$-Avenasterol & Total \\
\hline Butler & $0.91 \pm 0.01$ & $7.83 \pm 0.12$ & $1.41 \pm 0.01$ & $1.50 \pm 0.01$ & $132.05 \pm 0.14$ & $10.23 \pm 0.10$ & $0.96 \pm 0.02$ & $0.66 \pm 0.04$ & 155.5 \\
\hline Campanica & $1.02 \pm 0.02$ & $7.54 \pm 0.02$ & $1.57 \pm 0.04$ & $2.29 \pm 0.02$ & $120.82 \pm 0.13$ & $8.32 \pm 0.05$ & $2.17 \pm 0.02$ & $0.87 \pm 0.01$ & 144.6 \\
\hline Cosford & $2.38 \pm 0.01$ & $15.97 \pm 0.03$ & $2.32 \pm 0.01$ & $1.87 \pm 0.03$ & $170.41 \pm 0.11$ & $12.54 \pm 0.02$ & nd & $0.82 \pm 0.06$ & 206.3 \\
\hline Couplat & $1.40 \pm 0.06$ & $9.63 \pm 0.04$ & $2.04 \pm 0.04$ & $1.85 \pm 0.04$ & $151.86 \pm 0.47$ & $11.82 \pm 0.01$ & $1.07 \pm 0.03$ & $4.44 \pm 0.04$ & 184.1 \\
\hline Daviana & $1.24 \pm 0.05$ & $16.36 \pm 0.03$ & $2.50 \pm 0.03$ & $2.99 \pm 0.08$ & $219.60 \pm 0.04$ & $18.22 \pm 0.02$ & $1.03 \pm 0.06$ & $1.10 \pm 0.02$ & 263.0 \\
\hline Ennis & $1.42 \pm 0.01$ & $8.07 \pm 0.06$ & $1.99 \pm 0.02$ & $1.62 \pm 0.03$ & $152.36 \pm 0.09$ & $12.14 \pm 0.02$ & nd & $0.47 \pm 0.02$ & 178.1 \\
\hline F. Coutard & $2.86 \pm 0.01$ & $9.47 \pm 0.05$ & $1.64 \pm 0.06$ & $1.74 \pm 0.06$ & $135.85 \pm 0.10$ & $9.41 \pm 0.11$ & $1.19 \pm 0.00$ & $0.87 \pm 0.03$ & 163.0 \\
\hline Grossal & $0.65 \pm 0.02$ & $7.72 \pm 0.01$ & $1.21 \pm 0.01$ & $1.59 \pm 0.06$ & $112.90 \pm 0.10$ & $7.77 \pm 0.01$ & $1.40 \pm 0.05$ & $0.51 \pm 0.02$ & 133.8 \\
\hline Gunslbert & $1.01 \pm 0.04$ & $10.54 \pm 0.04$ & $1.68 \pm 0.01$ & $1.93 \pm 0.05$ & $146.21 \pm 0.27$ & $10.57 \pm 0.03$ & $1.42 \pm 0.02$ & $2.94 \pm 0.01$ & 176.3 \\
\hline Lansing & $2.17 \pm 0.03$ & $8.27 \pm 0.10$ & $2.26 \pm 0.03$ & $2.48 \pm 0.07$ & $149.84 \pm 0.08$ & $11.03 \pm 0.01$ & nd & $1.16 \pm 0.04$ & 177.2 \\
\hline L. Espanha & $1.71 \pm 0.01$ & $9.94 \pm 0.07$ & $2.06 \pm 0.02$ & $1.45 \pm 0.05$ & $149.92 \pm 0.14$ & $7.47 \pm 0.02$ & $0.53 \pm 0.03$ & $1.08 \pm 0.03$ & 174.2 \\
\hline M. Bollwiller & $1.69 \pm 0.01$ & $12.98 \pm 0.03$ & $1.93 \pm 0.01$ & $2.05 \pm 0.04$ & $156.62 \pm 0.11$ & $112.36 \pm 0.05$ & nd & $0.75 \pm 0.03$ & 188.4 \\
\hline Morell & $1.83 \pm 0.02$ & $12.45 \pm 0.02$ & $1.54 \pm 0.02$ & $1.79 \pm 0.02$ & $155.50 \pm 0.06$ & $11.85 \pm 0.07$ & $2.96 \pm 0.03$ & $1.42 \pm 0.03$ & 189.3 \\
\hline Negreta & $1.51 \pm 0.01$ & $9.89 \pm 0.02$ & $1.67 \pm 0.01$ & $1.50 \pm 0.07$ & $152.53 \pm 0.27$ & $9.31 \pm 0.03$ & $1.50 \pm 0.04$ & $0.87 \pm 0.01$ & 178.8 \\
\hline Pauetet & $1.65 \pm 0.03$ & $10.95 \pm 0.15$ & $2.33 \pm 0.06$ & $2.27 \pm 0.10$ & $152.62 \pm 0.14$ & $11.84 \pm 0.07$ & $1.58 \pm 0.01$ & $2.72 \pm 0.00$ & 186.0 \\
\hline R. Piemont & $1.02 \pm 0.02$ & $7.21 \pm 0.03$ & $1.36 \pm 0.02$ & $1.77 \pm 0.04$ & $107.98 \pm 0.25$ & $9.73 \pm 0.02$ & $3.61 \pm 0.09$ & $1.48 \pm 0.03$ & 134.2 \\
\hline Segorbe & $1.16 \pm 0.02$ & $12.35 \pm 0.03$ & $1.59 \pm 0.04$ & $1.97 \pm 0.02$ & $148.86 \pm 0.20$ & $13.15 \pm 0.00$ & $0.98 \pm 0.07$ & $1.28 \pm 0.01$ & 181.3 \\
\hline St. M. Jesus & $1.17 \pm 0.01$ & $8.04 \pm 0.01$ & $1.62 \pm 0.01$ & $1.56 \pm 0.05$ & $123.39 \pm 0.02$ & $7.97 \pm 0.03$ & $1.83 \pm 0.02$ & $0.67 \pm 0.03$ & 146.3 \\
\hline T. Giffoni & $1.49 \pm 0.05$ & $9.72 \pm 0.06$ & $1.79 \pm 0.03$ & $2.03 \pm 0.16$ & $162.89 \pm 0.18$ & $10.95 \pm 0.06$ & $1.29 \pm 0.11$ & $1.19 \pm 0.06$ & 191.3 \\
\hline Mean & 1.49 & 10.3 & 1.82 & 1.91 & 147.5 & 10.88 & 1.57 & 1.33 & 176.4 \\
\hline Range & $0.9-2.9$ & $7.2-16.4$ & $1.2-2.5$ & $1.5-3.0$ & $108.0-219.6$ & $7.5-18.2$ & $n d-3.6$ & $0.7-2.9$ & $134-263$ \\
\hline
\end{tabular}


Table 4 Sterol content range (mg/100 g of oil) of olive oil (OO) samples from different geographical origins

\begin{tabular}{|c|c|c|c|c|c|c|c|c|c|}
\hline Cultivar & Cholesterol & Campesterol & 1 Stigmasterol & Clerosterol & $\beta$-Sitosterol & $\Delta^{5}$-Avenasterol & $\Delta^{7}$-Stigmasterol & $\Delta^{7}$-avenasterol & Total \\
\hline European $\mathrm{OO}^{\mathrm{a}}$ & $n r$ & $2.5-11.4$ & $0.5-6.7$ & $n r$ & $68.3-261.0$ & $3.4-26.6$ & $n r$ & $n r$ & $\geq 100$ \\
\hline North African $\mathrm{OO}^{\mathrm{a}}$ & $n r$ & $5.9-6.4$ & $1.6-2.6$ & $n r$ & $154.5-185.1$ & $15.8-21.4$ & $0.1-0.4$ & $0.8-1.4$ & $180-230$ \\
\hline Turkish $\mathrm{OO}^{\mathrm{a}}$ & $n r$ & $3.3-7.4$ & $1.5-1.7$ & $n r$ & $100.0-202.5$ & $3.0-21.8$ & $0.2-0.9$ & $0.5-3.0$ & $110-170$ \\
\hline Spanish $\mathrm{OO}^{\mathrm{b}}$ & $0.5-1.0$ & $2.9-8.1$ & $0.7-1.5$ & $1.1-2.3$ & $89.8-177.2$ & $8.8 *-21.9$ & $0.2-0.5$ & $0.2-0.7$ & $111-203$ \\
\hline
\end{tabular}

hazelnut oils and olive oils. However, adulterations with low percentages of hazelnut oil may not be detected by this method and several parameters must be evaluated to assess the presence of hazelnut oil in olive oil as mentioned by Christopoulou et al. [21] and Parcerisa et al. [15].

In conclusion, hazelnuts are a rich source of oleic acid (about $80 \%$ ), which have been associated with beneficial health effects, and compared to olive oil has the advantage of presenting lower contents of saturated fatty acids. Hazelnuts also contain several phytosterols generally in higher amounts than most of the olive oil samples, which appears to be important bioactive compounds since they can inhibit intestinal absorption of cholesterol. Although some differences were noticed among cultivars, more data are needed in order to confirm if the composition of hazelnut lipid fraction differs enough to say if some of the cultivars are more suited in what health is concerned. Results from other crops and extending to other parameters, namely tocopherols and triglycerides, will be useful for such purpose.

Acknowledgment J.S. Amaral is grateful to Programa para o Desenvolvimento Educativo para Portugal (PRODEP III) for financial support.

\section{References}

1. Medeiros DM (2000) In: Wildman R (ed) Handbook of nutraceuticals and functional foods. CRC Press, London, pp 261-267

2. Hu FB, Stampfer MJ, Manson JE, Rimm EB, Colditz GA, Rosner BA, Speizer FE, Hennekens CH, Wilett WC (1998) Br Med J 317:1341-1345

3. Pérez-Jiménez F, López-Miranda J, Mata P (2002) Atherosclerosis 163:385-398

4. Pérez-Jiménez F, Castro P, López-Miranda J, Paz-Rojas E, Blanco A, López-Segura F, Velasco F, Marín C, Fuentes F, Ordovás JM (1999) Atherosclerosis 145:351-358

5. Kris-Etherton $P$ (1999) Circulation 100:1253-1258

6. Sabaté J, Radak T, Brown J Jr (2000) In: Wildman R (ed) Handbook of nutraceuticals and functional foods. CRC Press, London, pp 478-495

7. Fraser GE, Sabaté J, Beeson WL, Straham M (1992) Arch Intern Med 152:1416-1424

8. Durak Í, Köksal Í, Kaçmaz M, Büyükoçak S, Çimen B, Öztürk H (1999) Clin Chim Acta 284:113-115

9. Ozdemir F, Akinci I (2004) J Food Eng 63:341-347

10. Wong NC (2001) Can J Cardiol 17:715-721

11. Plat J, Mensink RP (2001) Nutr Metab Cardiovasc Dis 11:31-40

12. Awad AB, Fink CS (2000) J Nutr 130:2127-2130

13. Quílez J, García-Lorda P, Sala-Salvadó (2003) J Clin Nutr 22:343-351

14. Tapiero H, Townsend DM, Tew KD (2003) Biomed Pharmacother 57:321-325
15. Parcerisa J, Casals I, Boatella J, Codony R,Rafecas MJ (2000) Chrom A 881:149-158

16. Cercaci L, Rodriguez-Estrada MT, Lercker G (2003) J Chrom A 985:211-220

17. Ozen BF, Mauer LJ (2002) J Agric Food Chem 50:38983901

18. López-Díez EC, Bianchi G, Goodacre R (2003) J Agric Food Chem 51:6145-6150

19. Vigli G, Philippidis A, Spyros A, Dais P (2003) J Agric Food Chem 51:5715-5722

20. Christopoulou E, Lazaraki M, Komaitis M, Kaselimis K (2004) Food Chem 84:463-474

21. Zabaras D, Gordon MH (2004) Food Chem 84:475-483

22. Blanch GP, Caja MM, Castillo MLR, Herraiz M (1998) J Agric Food Chem 46:3153-3157

23. Firestone D, Reina RJ (1996) In: Ashurst PR, Dennis MJ (ed) Food authentication. Chapman \& Hall, London, pp. 198285

24. Ulberth F, Buchgraber M (2000) Eur J Lipid Sci Technol 102:687-694

25. Aparicio R, Aparicio-Ruíz R (2000) J Chrom A 881:93-104

26. Kamm W, Dionisi F, Hischenhuber C, Engel K (2001) Food Rev Int 17:249-290

27. Ozdemir F, Açkurt F, Kaplan M, Yildiz M, Loker M, Gurcan T, Birigen G, Okay A (2001) Food Chem 73:411-415

28. Alasalvar C, Shahidi F, Ohshima T, Wanasundara U, Yurttas HC, Liyanapathirana CM, Rodrigues FB (2003) J Agric Food Chem 51:3797-3805

29. Parcerisa J, Richardson DG, Rafecas M, Codony R, Boatella J (1998) J Chrom A 805:259-268

30. Açkurt F, Ozdemir M, Birigen G, Loker M (1999) Food Chem 65:309-313

31. Benitez-Sánchez PL, León-Camacho M, Aparicio R (2003) Eur Food Res Technol 218:13-19

32. Bada JC, Léon- Camacho M, Prieto M, Alonso L (2004) Eur J Lipid Sci Technol 106:294-300

33. Savage GP, McNeil DL (1998) Int J Food Sci Nutr 49:199_ 203

34. Parcerisa J, Boatelle J, Codony R, Rafecas M, Castellote AI, García J, López A, Romero A (1995) J Agric Food Chem 43:13-16

35. Parcerisa J, Richardson D, Rafecas M, Codony R, Boatella J (1997)J Agric Food Chem 45:3887-3890

36. Ruggeri S, Cappelloni L, Gambelli S, Carnovale E (1998) Ital J Food Sci 3:243-252

37. Parcerisa J, Rafecas M, Castellote AI, Codony R, Farràn A, Garcia J, Gonzalez C, López A, Romero A, Boatelle J (1995) Food Chem 53:71-74

38. Bonvehí JS, Coll FV (1993) Food Chem 48:237-241

39. AOAC (2000) In: Horwitz W (ed) Official methods of analysis of AOAC international Vol. II, 40:1-3

40. Greenfield H, Southgate DAT (1992) Food composition data. Production, management and use. Elsevier Applied Science, London and New York

41. Amaral JS, Casal S, Pereira JA, Seabra RM, Oliveira BPP (2003) J Agric Food Chem 51:7698-7702

42. NP EN ISO 12228 (1999) Animal and vegetable fats and oils - Determination of individual and total sterols contents - Gas chromatographic method 
43. Salvador MD, Aranda F, Gómez-Alonso S, Fregapane G (2003) Food Chem 80:359-366

44. Mannina L, Dugo G, Salvo F, Cicero L, Ansenelli G, Calgagni C, Segre A (2003) J Agric Food Chem 51:120-127

45. Ollivier D, Artaud J, Pinatel C, Burbec JP, Guérère MJ (2003) Agric Food Chem 51:5723-5731
46. Bernardo-Gil MG, Grenha J, Santos J, Cardoso P (2002) Eur J Lipid Sci Technol 104:402-409

47. Casas JS, Bueno EO, García MM, Cano MM (2004) Food Chem 87:225-230

48. Álamo RMR, Fregapane G, Aranda F, Gómez-Alonso S, Salvador MD (2004) Food Chem 84:533-53 